Vol. 4, No. 1, Juni 2020, hal. 11-21

ISSN 2598-3245 (Print), ISSN 2598-3288 (Online)

DOI: http://doi.org/10.31961/eltikom.v4i1.156

Tersedia online di http://eltikom.poliban.ac.id

\title{
DIAGNOSA HEPATITIS A MENGGUNAKAN METODE DEMPSTER - SHAFER
}

\author{
Ridha Pratiwi, Septi Andryana, dan Aris Gunaryati \\ Fakultas Teknologi Komunikasi dan Informatika, Universitas Nasional, Jakarta, Indonesia \\ e-mail: ridha.pratiwi00@gmail.com, septi.andryana@civitas.unas.ac.id, aris.gunaryati@civitas.unas.ac.id
}

Diterima 29 Desember 2019 - Direvisi 9 Januari 2020 - Disetujui 11 Januari 2020

\begin{abstract}
Hepatitis A is an inflammatory disease that occurs in the liver, which is caused due to an infection by the HAV virus, besides the lack of public attention to environmental hygiene, food, and drinks that are not hygienic, the high cost of consultation, and unhealthy sex is also a major factor of development of the disease. To overcome these problems, a system was created that could assist the community in detecting early, as well as providing information related to hepatitis A, namely, by utilizing an expert system that uses the Dempster - Shafer method, which is a method used to find the certainty of symptoms that occur. has been inputted before, and produces output in the form of the diagnosis, treatment, solution, and symptoms that have been selected. This research was conducted by simulating a system of randomly selected symptoms, totaling 100 test data, accompanied by relevant experts. So that the accuracy of $92 \%$ of the data is according to the expert and $8 \%$ of the data is not according to the expert. The results of these tests indicate that this expert system has been able to conduct early diagnoses related to hepatitis A by the Dempster - Shafer method.
\end{abstract}

Keywords: dempster - shafer, expert system, hepatitis A.

\section{ABSTRAK}

Hepatitis A merupakan penyakit peradangan yang terjadi pada hati, yang disebabkan karena adanya infeksi oleh virus HAV, selain itu kurangnya perhatian masyarakat terhadap kebersihan lingkungan, makanan dan minuman yang tidak higenis, mahalnya biaya konsultasi, serta hubungan seks yang tidak sehat juga merupakan faktor utama dari berkembangnya penyakit tersebut. Untuk mengatasi permasalahan tersebut, dibuatlah suatu sistem yang dapat membantu masyarakat dalam mendeteksi dini, serta memberikan informasi terkait penyakit hepatitis A yaitu, dengan memanfaatkan sebuah sistem pakar yang menggunakan metode Dempster - Shafer, yang merupakan sebuah metode yang digunakan untuk mencari nilai kepastian dari gejala yang telah diinputkan sebelumnya, dan menghasilkan output berupa hasil diagnosis, penanganan, solusi, dan gejala yang telah dipilih. Penelitian ini dilaksanakan dengan mensimulasikan sistem dari gejala yang dipilih secara acak, sebanyak 100 data uji, dengan didampingi oleh pakar terkait. Sehingga diperoleh hasil akurasi sebesar 92\% data yang sesuai dengan pakar dan $8 \%$ data tidak sesuai dengan pakar. Dari hasil pengujian tersebut menunjukan bahwa sistem pakar ini telah mampu untuk melakukan diagnosa dini terkait penyakit hepatitis A dengan metode Dempster Shafer.

Kata Kunci: dempster - shafer, hepatitis A, sistem pakar.

\section{PEndahuluan}

$\mathrm{H}$ EPATITIS A merupakan sebuah penyakit yang menyerang organ hati, yang disebabkan oleh virus yang bernama HAV. Virus ini biasanya menular lewat makanan atau minuman yang telah terkontaminasi, tinggal di wilayah yang banyak terkena hepatitis A, serta perilaku seks yang menyimpang. Gejala umum yang paling sering dirasakan yaitu demam, mual, hilang nafsu makan dan kulit kuning [1]. Kurangnya pengetahuan terkait penyakit tersebut dapat mengakibatkan terlambatnya penanganan dan bertambah parahnya penyakit yang diderita, selain itu mahalnya biaya untuk konsultasi menjadi salah satu faktor permasalahan yang terjadi saat ini, sehingga mengakibatkan masih banyaknya masyarakat yang berusaha untuk merawatnya sendiri tanpa tahu benar atau tidaknya terkait penyakit 


\section{Jurnal ELTIKOM : Jurnal Teknik Elektro, Teknologi Informasi dan Komputer}

yang diderita tersebut [2], untuk perawatan bagi penderita yang terkena penyakit ini bisa dengan menerapkan pola hidup sehat serta memenuhi nutrisi yang cukup [3].

Untuk memperkuat penelitian ini, penulis mengambil beberapa acuan tentang sistem pakar yang digunakan dalam bidang ilmu kesehatan dengan metode Dempster - Shafer, yang dijadikan sebagai referensi bagi penulis, salah satunya yaitu pada penelitian tentang diagnosa penyakit hepatitis dengan memanfaatkan 29 gejala, dapat memperoleh tingkat akurasi sebesar $90 \%$ dari 20 data uji [4], selain itu pada penelitian tentang kulit wajah manusia dengan metode Dempster - Shafer, menampilkan tampilan website yang user friendly dengan nilai keakuratan 44.4\% [5], pada penelitian tentang penyakit TBC dengan menggunakan metode Dempster - Shafer menghasilkan diagnosa dari penyakit TBC itu sendiri dengan menginputkan beberapa gejala yang diderita, dengan keakuratan $57.83 \%$ [6], dan pada penelitian tentang penyakit tropis dengan 9 jenis penyakit diperoleh tingkat akurasi sebesar 94.23\% [7].

Berdasarkan masalah tersebut maka, diperlukannya suatu teknologi yang dapat membantu, permasalahan yang ada. Salah satu yang dapat digunakan yaitu, dengan memanfaatkan kecerdasan buatan salah satunya sistem pakar [8]. Sistem pakar yaitu salah satu cabang dari kecerdasan buatan yang dapat mengadopsi kecerdasan dari pakar [9], yang dibantu dengan menggunakan algoritma Dempster Shafer yang memiliki tingkat akurasi cukup tinggi, yang dilihat dari penelitian sebelumnya.

Adapula tujuan dari penelitian ini yaitu, untuk melakukan diagnosa dini terkait penyakit hepatitis A dengan menggunakan aplikasi sistem pakar berbasis website, dengan menerapkan metode Dempster Shafer agar nantinya pengguna dapat mengetahui seberapa besar kemungkinan terindikasi penyakit tersebut, dan dapat meminimalisirnya dengan adanya keterangan untuk pencegahan serta solusi yang nantinya dapat memperbaiki kekurangan pada penelitian sebelumnya terkait penyakit hepatitis.

\section{METODE PENELITIAN}

Dalam membangun suatu sistem, tentunya dibutuhkan metode dan teknik yang akan digunakan. Untuk teknik yang digunakan yaitu, teknik pengumpulan data yang dapat membantu penulis dalam memberikan data - data konkrit terkait penelitian yang sedang dilakukan, mulai dari tahap awal mencari data terkait penyakit tersebut, hingga nantinya mendapatkan kesimpulan atau hasil akhir, yang sesuai dengan output yang diinginkan. Dan untuk metode yang digunakan pada sistem ini, penulis menggunakan metode Dempster - Shafer, yang merupakan sebuah metode perhitungan matematika, untuk memperoleh nilai densitas terbesar dari gejala yang telah dimasukkan oleh user, dengan menggunakan perhitungan matriks, yang nantinya akan menghasilkan output berupa, hasil diagnosa, gejala yang telah dipilih, solusi, serta penanganannya.

\section{A. Sistem Pakar}

Sistem pakar adalah, sebuah sistem komputer yang dapat meniru suatu kemampuan dari seorang pakar [10][11]. Dalam hal ini pakar yang dimaksud yaitu seseorang yang memiliki wawasan terkait bidang ilmu yang dikuasai agar nantinya dapat membantu dalam memecahkan suatu masalah dengan memanfaatkan kemajuan teknologi saat ini [12]. Sistem pakar sendiri, dapat dimanfaatkan kedalam beberapa bidang seperti bidang kesehatan, pemerintahan, serta bidang apapun yang memanfaatkan pengambilan keputusan untuk memperoleh hasil yang diinginkan.

\section{B. Teknik Pengumpulan Data}

Adapula teknik yang digunakan dalam pengumpulan data pada penelitian ini, diantaranya yaitu, melakukan studi Pustaka dengan mengutip dari beberapa sumber bacaan yang terkait baik dari jurnal, maupun buku teks. Lalu selain itu penulis juga melakukan wawancara kepada pakar terkait penyakit tersebut [13]. Teknik wawancara ini, digunakan untuk memperkuat hasil dari penelitian, serta untuk mendapatkan penjelasan yang akurat terkait gejala - gejala, dan masalah yang berkaitan dengan penelitian, agar data yang diperoleh bersifat valid. Adapula flowchart penelitian yang digunakan sebagai gambaran dari penelitian yang sedang penulis lakukan, dapat dilihat pada Gambar 1. 


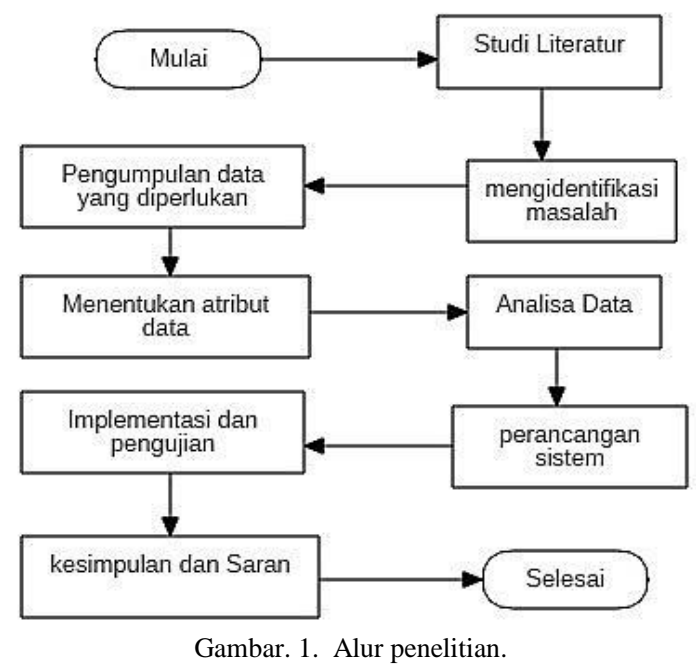

Dari Gambar 1 dapat dilihat bahwa perancangan penelitian dimulai dengan studi literatur dari yang diperoleh dari jurnal acuan / buku, lalu melakukan pengidentifikasi masalah yang akan diteliti tentang pendiagnosaan penyakit hepatitis A. Selanjutnya pengumpulan data yang diperlukan dengan menggunakan jurnal, buku serta wawancara dengan dokter, selanjutnya pengumpulan atribut dari data yang akan dibahas nantinya, setelah itu dilakukan analisa data yang telah didapat agar sesuai dengan kebutuhan, kemudian melakukan perancangan sistem dengan menggunakan bahasa pemograman PHP. Lalu melakukan pengujian sistem, dan langkah terakhir yang dilakukan yaitu pembuatan kesimpulan dan saran dari hasil penelitian yang telah dibuat hingga, didapatkan output yang sesuai dengan keinginan, yaitu dapat mendiagnosa penyakit hepatitis A.

\section{Metode Dempster - Shafer}

Pada penelitian ini, metode yang digunakan adalah metode Dempster - Shafer. Metode Dempster Shafer sendiri, yaitu suatu teori matematika untuk melakukan pembuktian berdasarkan tingkat kepercayaan dan pemikiran yang masuk akal. Teori Dempster - Shafer ditulis dalam suatu interval sebagai berikut: [Belief, Plausibility] [2][14]. Alur dari metode Dempster - Shafer ini bisa dilihat dalam bentuk flowchart seperti Gambar 2.

Gambar 2 menjelaskan tentang alur dari perhitungan dengan menggunakan metode ini dimulai dari

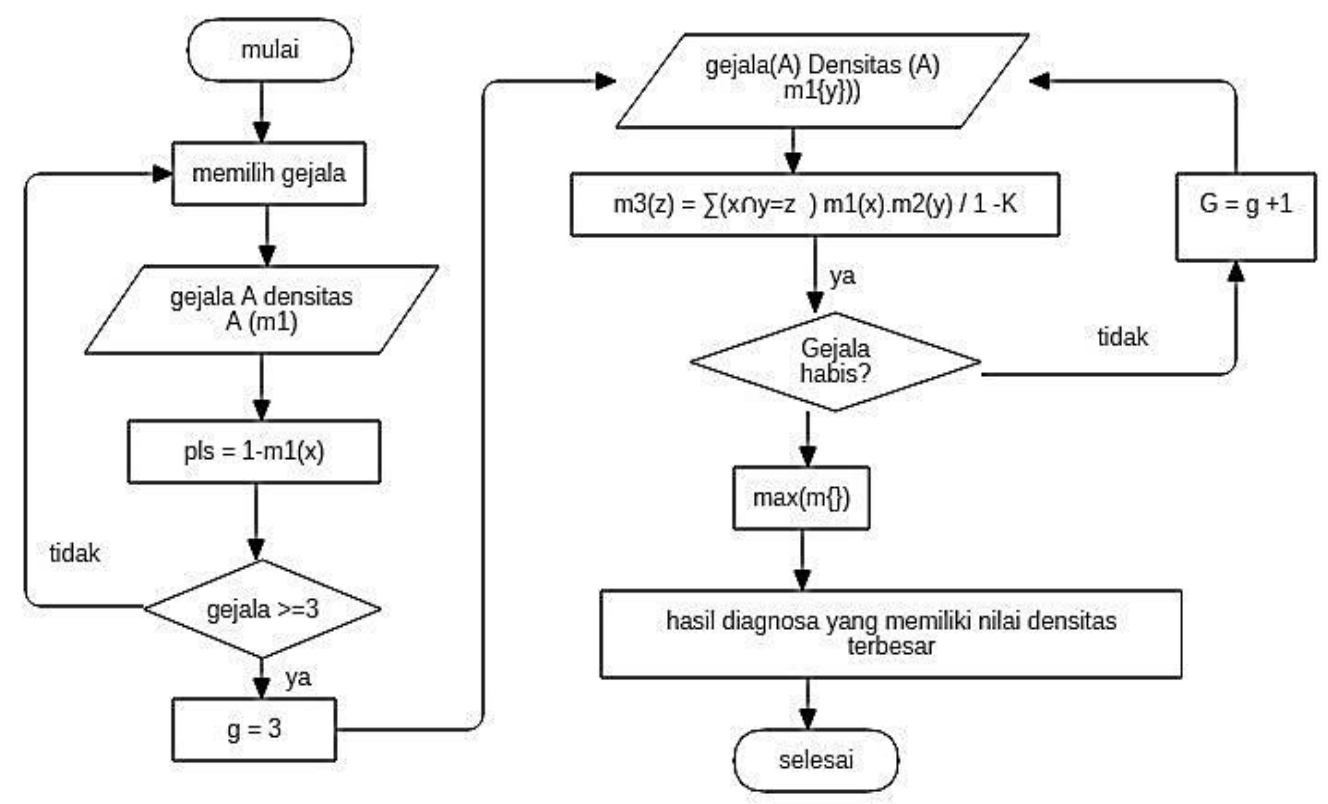

Gambar. 2. Alur metode dempster - shafer. 


\section{Jurnal ELTIKOM : Jurnal Teknik Elektro, Teknologi Informasi dan Komputer}

menginputkan gejala, yang telah memilki nilai belief (Bel) dari pakar. Nilai belief sendiri memiliki range nilai 0 - 1 dimana jika bernilai 0 maka tidak ada nilai bukti dan jika 1 menunjukan adanya kepastian [15] yang ditunjukan pada Persamaan 1 berikut ini:

$$
\operatorname{Bel}(x)=\sum_{y \subseteq x} m(y) .
$$

Selanjutnya menghitung nilai plausibility. Plausbility $(\mathrm{Pl})$ akan mengurangi tingkat kepastian $(\mathrm{Bel})$ dari evidence, pada plausability range yang dimiliki bernilai 0 sampai 1 . Dimana jika yakin akan $X$ maka dikatakan nilai $\operatorname{Bel}(x)=1$, sehingga nilai dari $P l(X)$ adalah 0 [15]. Nilai plausability juga di notasikan pada Persamaan 2 berikut ini:

$$
P l s(x)=1-\operatorname{Bel}\left(x^{\prime}\right) .
$$

Lalu pada langkah selanjutnya, jika gejala yang diinpukan sama dengan tiga, maka akan membentuk densitas baru dan melakukan perhitungan Dempster - Shafer dinotasikan dengan rumus seperti pada Persamaan 3 sebagai berikut:

$$
m_{3}(z)=\frac{\sum_{x \cap y=z} m 1(x) \cdot m 2(y)}{1-K} .
$$

$m_{3}(\mathrm{z})$ adalah mass function dari evidence $\mathrm{z}$. $\mathrm{m} 1$ (x) adalah mass function dari evidence $x . m 2(y)$ adalah mass function dari evidence $y . \sum_{x \cap y=z} m 1(x) . m 2(y)$ adalah hasil dari perkalian $m 1$ dan $m 2 . K$ adalah jumlah konflik evidence jika ada irisan kosong. Lalu jika gejala habis, langkah selanjutnya dengan mencari nilai densitas terbesar, jika tidak tambahkan gejala lagi dan mengulangi perhitungan Dempster - Shafer itu lagi, hingga didapatkannya nilai densitas yang terbesar untuk dijadikan hasil akhir dalam melakukan diagnosa.

\section{Alur Kerja Sistem}

Dalam pembuatan suatu sistem diperlukan suatu alur agar penguna dapat mengerti maksud dari sistem tersebut, yang digambarkan dalam bentuk flowchart sistem, seperti Gambar 3.

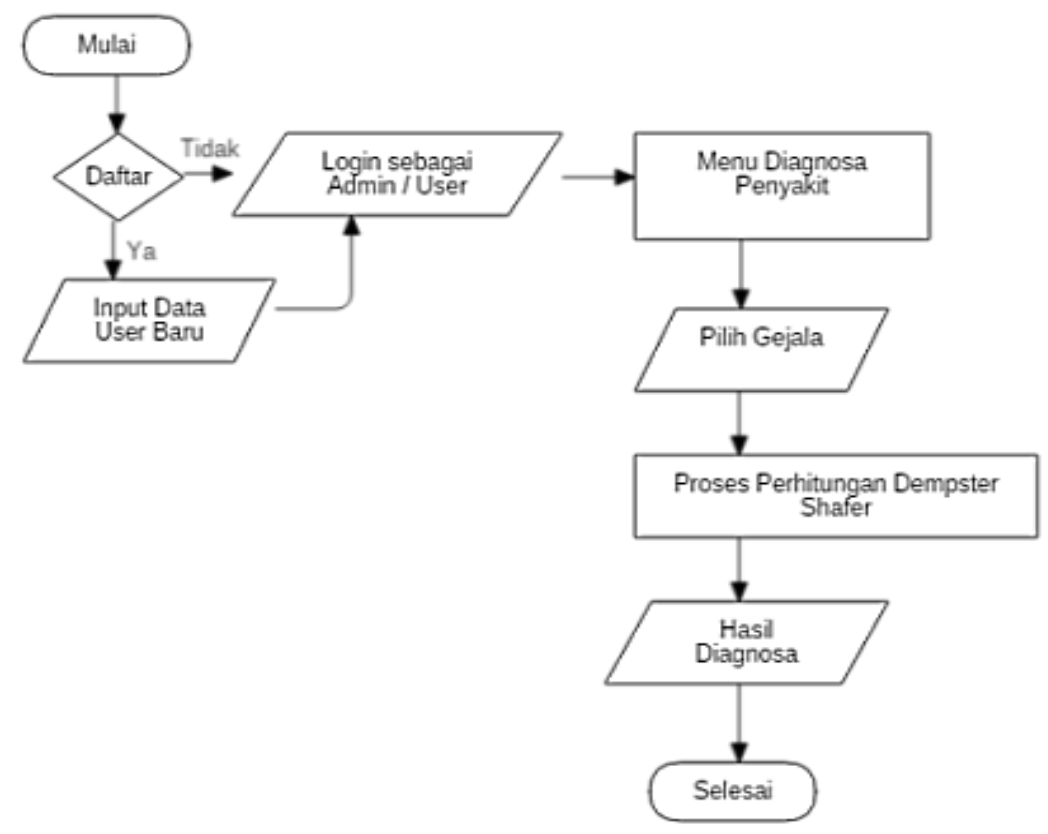

Gambar. 3. Alur sistem pakar hepatitis A.

Pada gambar 3, sistem memunculkan login bagi yang sudah memiliki akun, sedangkan bila belum memiliki akun, maka sistem akan mengarahkan untuk melakukan register terlebih dahulu dengan menginputkan data user baru, selanjutnya sistem akan memunculkan menu diagnosa penyakit, untuk 


\section{Jurnal ELTIKOM : Jurnal Teknik Elektro, Teknologi Informasi dan Komputer}

melakukan pemilihan gejala, lalu sistem akan melakukan proses perhitungan menggunakan metode Dempster - Shafer, yaitu dengan mencari nilai densitas terbesar, yang nantinya akan mengeluarkan hasil diagnosa penyakit berdasarkan gejala yang telah dipilih oleh $u$ ser.

\section{E. Usecase Diagram}

Pada Gambar 4, dijelaskan bahwa sistem memiliki 2 pengguna yakni untuk admin dan user yang menggunakan sistem pakar ini. Untuk user dapat melakukan login, melakukan konsultasi penyakit, melihat dan mencetak hasil konsultasi penyakit, dan melihat riwayat konsultasinya itu. Sedangkan, untuk admin dapat melakukan login admin ke dashboard untuk melihat dan menghapus data pengguna, melihat daftar gejala, serta dapat melihat, menghapus, dan mencetak hasil dari konsultasi user yang nantinya akan dijadikan laporan atau arsip bagi admin.

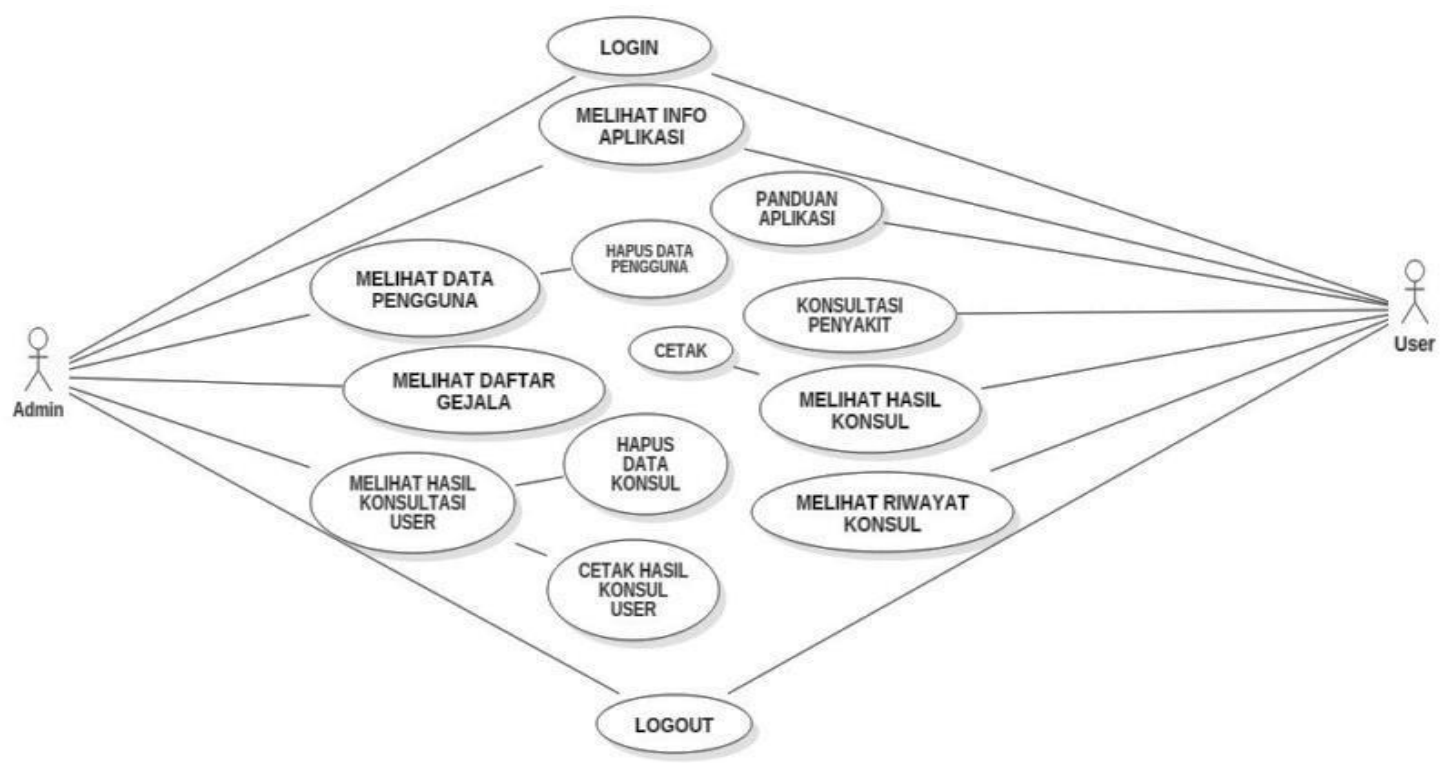

Gambar. 4. Usecase diagram sistem pakar penyakit hepatitis A.

\section{F. Activity Diagram}

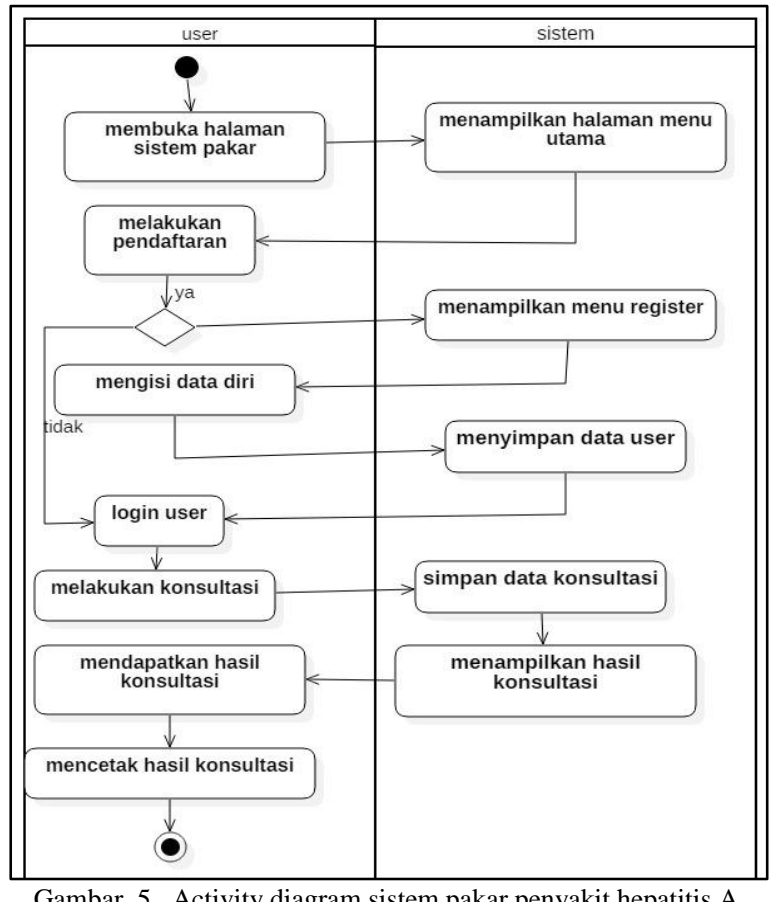

Pada gambar 5, merupakan rancangan activity diagram untuk user. Kegiatan dimulai dari user 
TABEL 1

HASIL DARI GEJALA YANG DIPILIH.

\begin{tabular}{cc}
\hline \hline Kode & OUTPUT \\
\hline $\mathrm{O} 1$ & Terindikasi hepatitis A \\
$\mathrm{O} 2$ & Tidak terindikasi hepatitis A \\
\hline \hline
\end{tabular}

TABEL 2

GEJALA DARI PENYAKIT HEPATITIS A.

\begin{tabular}{|c|c|c|c|c|c|}
\hline Kode & NAMA GEJALA & O1 & $\mathrm{O} 2$ & BELIEF & PLAUSABILITY \\
\hline G1 & Merasakan Demam & $\checkmark$ & $\checkmark$ & 0,6 & 0,4 \\
\hline G2 & Mengalami jaundince ( anggota tubuh menguning) & $\checkmark$ & $\checkmark$ & 0,5 & 0,5 \\
\hline G3 & Mengkonsumsi sayuran mentah & $\checkmark$ & & 0,8 & 0,2 \\
\hline G4 & Makan - makanan sembarangan & $\checkmark$ & & 0,7 & 0,3 \\
\hline G5 & Lingkungan sekitar banyak yang terkena hepatitis & $\checkmark$ & & 0,7 & 0,3 \\
\hline G6 & Perut membesar & & $\checkmark$ & 0,7 & 0,3 \\
\hline G7 & Urin berwarna gelap & $\checkmark$ & & 0,6 & 0,4 \\
\hline G8 & Berpergian ke wilayah afrika, asia tenggara, dan tengah & $\checkmark$ & $\checkmark$ & 0,4 & 0,6 \\
\hline G9 & Merasakan nyeri sendi & & $\checkmark$ & 0,6 & 0,4 \\
\hline G10 & Merasakan mual tetapi tidak bisa dimuntahkan & $\checkmark$ & $\checkmark$ & 0,4 & 0,6 \\
\hline G11 & Merasakan nyeri otot & & $\checkmark$ & 0,5 & 0,5 \\
\hline G12 & Memiliki riwayat keluarga hepatitis & $\checkmark$ & & 0,8 & 0,2 \\
\hline G13 & Merasa bingung (depresi) & $\checkmark$ & $\checkmark$ & 0,4 & 0,6 \\
\hline G14 & Tinggal diwilayah sanitasi buruk & $\checkmark$ & & 0,7 & 0,3 \\
\hline G15 & Tidak melakukan vaksin HBAV saat anak & $\checkmark$ & & 0,8 & 0,2 \\
\hline G16 & Hilang nafsu makan & & $\checkmark$ & 0,7 & 0,3 \\
\hline G17 & Telapak tangan memerah & $\checkmark$ & & 0,5 & 0,5 \\
\hline G18 & Mengalami persaan sakit yang samar - samar & & $\checkmark$ & 0,7 & 0,3 \\
\hline G19 & Sering muntah & & $\checkmark$ & 0,8 & 0,2 \\
\hline G20 & Muncul spider angioma dikulit & $\checkmark$ & & 0,6 & 0,4 \\
\hline G21 & Minum - minuman alcohol & $\checkmark$ & & 0,6 & 0,4 \\
\hline $\mathrm{G} 22$ & Lahir dari ibu yang tekena hepatitis saat hamil & $\checkmark$ & & 0,8 & 0,2 \\
\hline G23 & Pernah melakukan tranfusi darah yang tidak jelas & $\checkmark$ & $\checkmark$ & 0,6 & 0,4 \\
\hline G24 & Penggunaan barang pribadi secara bersamaan & & $\checkmark$ & 0,7 & 0,3 \\
\hline G25 & Berat badan menurun & & $\checkmark$ & 0,7 & 0,3 \\
\hline G26 & Merasa lelah setiap saat & $\checkmark$ & $\checkmark$ & 0,5 & 0,5 \\
\hline G27 & Menggunakan jarum suntik bersamaan & & $\checkmark$ & 0,7 & 0,3 \\
\hline G28 & Perut terasa kembung & & $\checkmark$ & 0,8 & 0,2 \\
\hline G29 & Pernah melakukan dental procedure & $\checkmark$ & $\checkmark$ & 0,6 & 0,4 \\
\hline G30 & Sering jajan disembarang tempat. & $\checkmark$ & & 0,8 & 0,2 \\
\hline
\end{tabular}

TABEL 3

BASIS PENGETAHUAN RULE (ATURAN).

\begin{tabular}{cll}
\hline \hline \multirow{2}{*}{ Kode } & \multicolumn{1}{c}{ OutPuT } & \\
\hline O1 & Terindikasi hepatitis A & G1, G2, G3, G4, G5, G7, G8, ,G10, G12, G13, G14, G15,G17, G20, G21, G22, G23, G26, \\
& G29, G30 & ATURAN \\
O2 & Tidak terindikasi hepatitis A & G1, G2, G6, G8, G9, G10, G11, G13, G16, G18, G19, G23, G24, G25, G26, 27, G28, G29. \\
\hline \hline
\end{tabular}




\section{Jurnal ELTIKOM : Jurnal Teknik Elektro, Teknologi Informasi dan Komputer}

halaman menu utama yang akan dilihat oleh user, kemudian untuk user baru akan diarahkan untuk melakukan pendaftaran terlebih dahulu dan sistem akan menampilkan menu registerasi, lalu user melakukan pengisian data diri, sistem akan menyimpan data dari user yang selanjutnya, akan melakukan login, tetapi bila user yang sebelumnya telah melakukan pendaftaran dapat langsung melakukan login, yang dilanjutkan dengan melakukan konsultasi, selanjutnya sistem akan menyimpan dan menampilkan hasil konsultasi, selanjutnya user akan mendapatkan hasil konsultasi dan dapat mencetaknya.

\section{G. Basis Pengetahuan}

Basis pengetahuan adalah sekumpulan fakta - fakta yang diperoleh dari sumber terkait [13]. Dalam membangun sebuah aplikasi sistem pakar, dibutuhkannya sebuah data - data yang berasal dari pakar serta buku. Pada penelitian ini buku yang digunakan, adalah buku yang berjudul "Hepatitis A Cegah Penularannya" oleh Dr. J.B. Suharjo B. Cahyono, Sp.PD [1].

Pada Tabel 1 tersebut merupakan basis gejala dari output yang ada pada sistem pakar yang dibuat, yang berisi kode $\mathrm{O} 1$ untuk output terindikasi hepatitis $\mathrm{A}$ dan kode $\mathrm{O} 2$ untuk mendefinisikan bahwa tidak terindikasi hepatitis A.

Pada Tabel 2 berisi tentang basis pengetahuan dari gejala penyakit hepatitis A, terdapat pula nilai belief (Bel) dan nilai plausibility (Pl), untuk gejala dan nilai tersebut diperoleh langsung dari pakar dan buku panduan yang berjudul "Hepatitis A Cegah Penularannya" [1].

Pada Tabel 3 yaitu adalah tabel basis pengetahuan rule (aturan) yang didalamnya berisi aturan - aturan yang mengarahkan pengguna untuk dapat memecahkan masalah pada sistem ini. Dimana untuk kode $\mathrm{O} 1$ berisi 20 aturan dan untuk kode $\mathrm{O} 2$ berisi 18 aturan.

\section{H. Analisis Metode Dempster - Shafer}

Dengan melakukan pengujian konsultasi, dengan memilih 3 gejala yang dipilih oleh user yaitu :

1) memiliki riwayat keluarga hepatitis,

2) hilang nafsu makan, dan

3) mengalami perasaan sakit yang samar - samar.

Gejala pertama adalah

$\mathrm{m} 1(\mathrm{O} 1)=0,8$

$\operatorname{ml}(\theta)=1-0,8=0,2$.

Gejala kedua adalah

$\mathrm{m} 2(\mathrm{O} 2)=0,7$

$\mathrm{m} 2(\theta)=1-0,7=0,3$.

TABEL 4

PERHITUNGAN MATRIKS PERTAMA DENGAN DEMPSTER - SHAFER.

\begin{tabular}{ccc}
\hline \hline & $\mathrm{M} 2(\mathrm{O} 2)=0,7$ & $\mathrm{M} 2(\Theta)=0,3$ \\
\hline $\mathrm{M} 1(\mathrm{O} 1)=0,8$ & $(\theta)=0,56$ & $\mathrm{O} 1=0,24$ \\
$\mathrm{M} 1(\Theta)=0,2$ & $\mathrm{O} 2=0,14$ & $(\theta)=0,06$ \\
\hline \hline
\end{tabular}

$\mathrm{O} 1=0,24 / 1-0,56=0,24 / 0,44=0,55$

$\mathrm{O} 2=0,14 / 1-0,56=0,32$

$\Theta=1-(\mathrm{O} 1+\mathrm{O} 2)=1-0,87=0,13$.

Gejala ketiga adalah

$\mathrm{m} 4(\mathrm{O} 2)=0,7$

$\mathrm{m} 4(\theta)=0,3$.

TABEL 5

PERHITUNGAN MATRIKS ITERASI KEDUA DENGAN DEMPSTER - SHAFER.

\begin{tabular}{ccc}
\hline \hline & $\mathrm{M} 4(\mathrm{O} 2)=0,7$ & $\mathrm{M} 4(\Theta)=0,3$ \\
\hline $\mathrm{M} 3(\mathrm{O} 1)=0,55$ & $\Theta=0,4$ & $\mathrm{O} 1=0,2$ \\
$\mathrm{M} 3(\mathrm{O} 2)=0,32$ & $\mathrm{O} 2=0,2$ & $\mathrm{O} 2=0,1$ \\
$\mathrm{M} 3(\Theta)=0,13$ & $\mathrm{O} 2=0,1$ & $\Theta=0,04$ \\
\hline \hline
\end{tabular}




\section{Jurnal ELTIKOM : Jurnal Teknik Elektro, Teknologi Informasi dan Komputer}

$\mathrm{O} 1=0,2 / 1-0,4=0,34$

$\mathrm{O} 2=(0,2+0,1+0,1) / 1-0,4=0,4 / 0,6=0,67$.

Dari hasil perhitungan manual diatas dapat dilihat bahwa nilai kepercayaan terbesar ada pada $\mathrm{O} 2$ yang berarti "Tidak terindikasi hepatitis A" yaitu sebesar 0,67 dan bila di presentasikan menjadi 0,67 x 100\% $=67 \%$, yang bila dibandingkan dengan sistem, hasilnya pun juga sesuai dengan sistem yang telah dibuat.

\section{Tampilan Sistem Pakar}

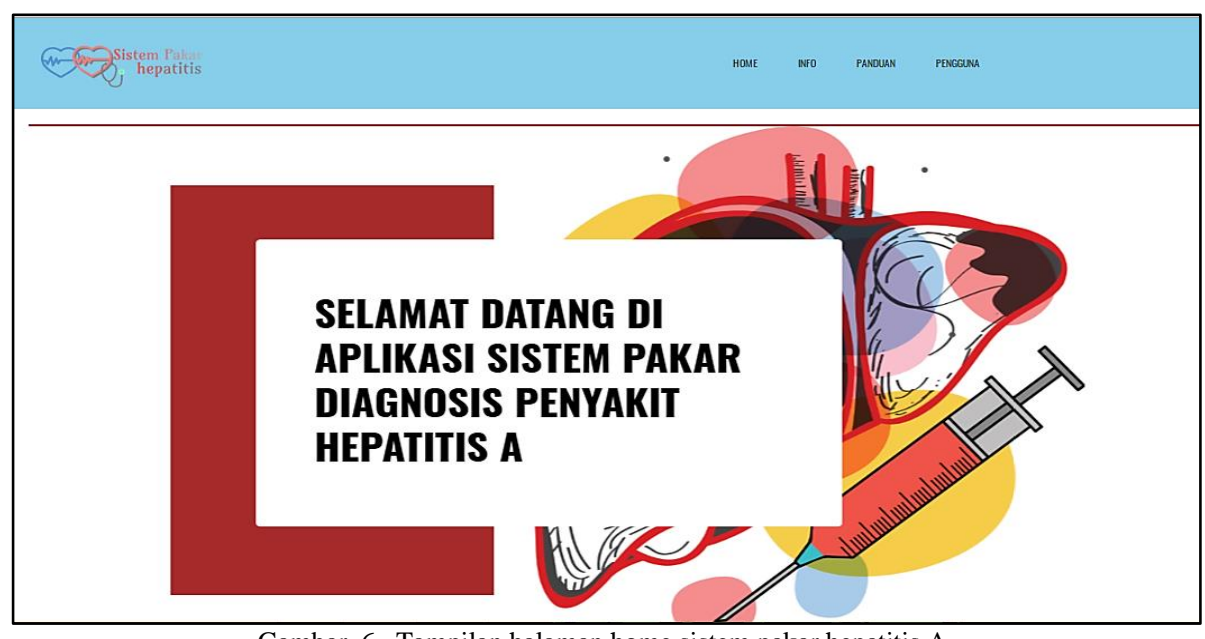

Gambar. 6. Tampilan halaman home sistem pakar hepatitis A.

Pada Gambar 6 adalah tampilan awal Halaman home sebelum user / admin melakukan login, pada halaman ini terdapat info mengenai penyakit hepatitis A, panduan penggunaan aplikasi serta menu untuk login ataupun mendaftar baru.

\section{HOME INFO PANDUAN KONSULTASI HISTORY LOGOUT}

\section{Silahkan pilih apa yang anda rasakan}

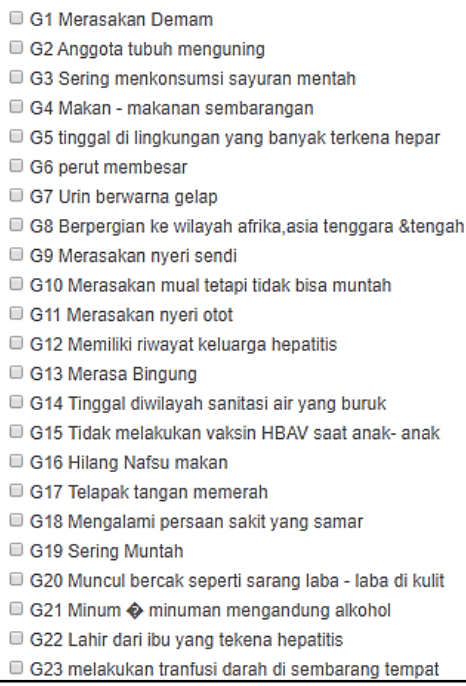

Gambar. 7. Tampilan halaman konsultasi yang berisi daftar gejala.

Pada Gambar 7, merupakan tampilan halaman konsultasi, yang digunakan para pengguna untuk memilih gejala yang dirasakan, terdapat 30 gejala yang disediakan untuk nantinya dipilih oleh user.

Pada Gambar 8, merupakan tampilan hasil diagnosa dari sistem, yang didalamnya terdapat hasil 


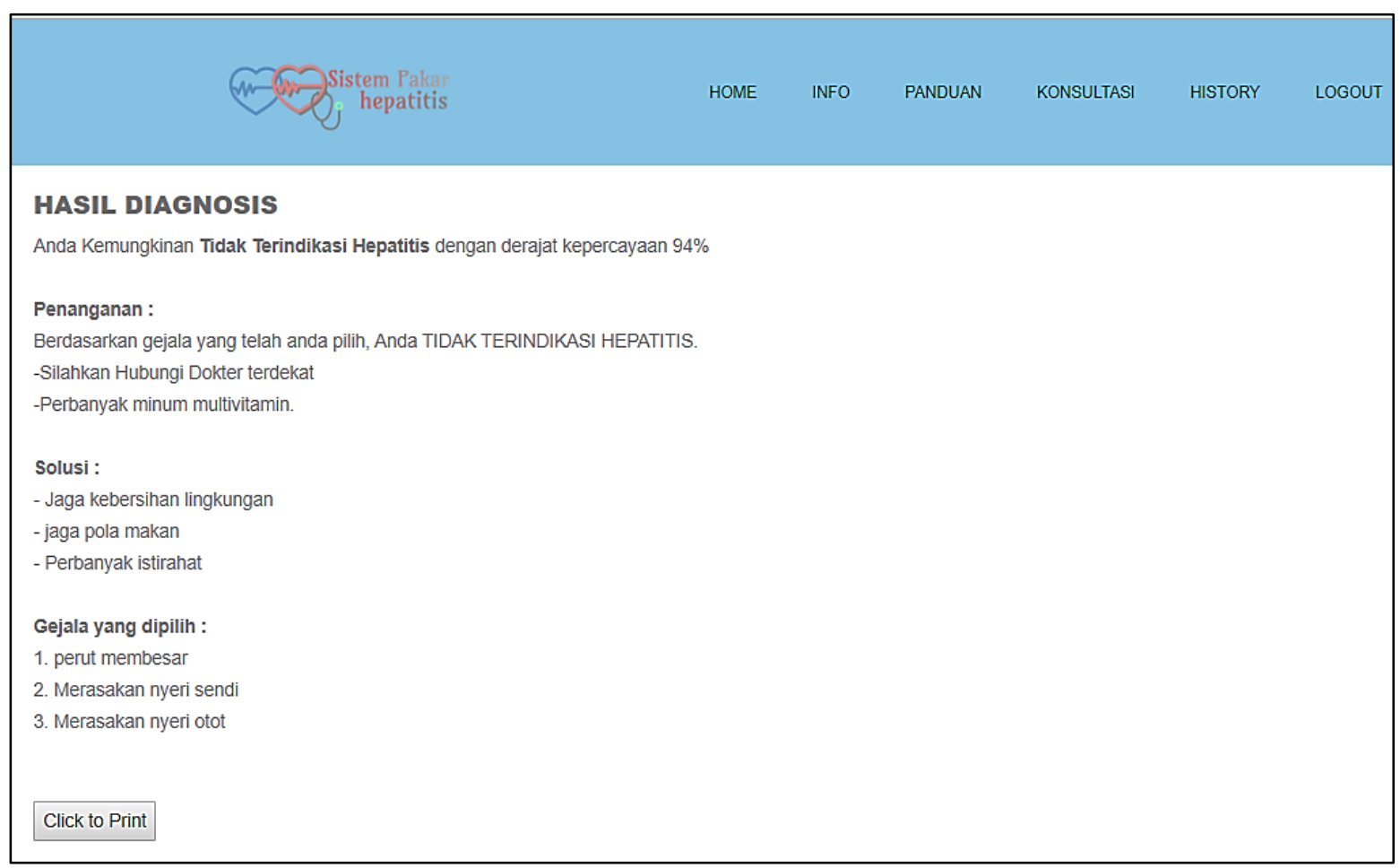

Gambar. 8. Tampilan halaman hasil diagnosis.

diagnosa yang dilengkapi dengan tingkat kepercayaan, penanganan, solusi, serta daftar gejala yang telah dipilih. Selain itu terdapat pula tombol print, yang dapat digunakan oleh pengguna agar dapat mencetak hasil diagnosanya.

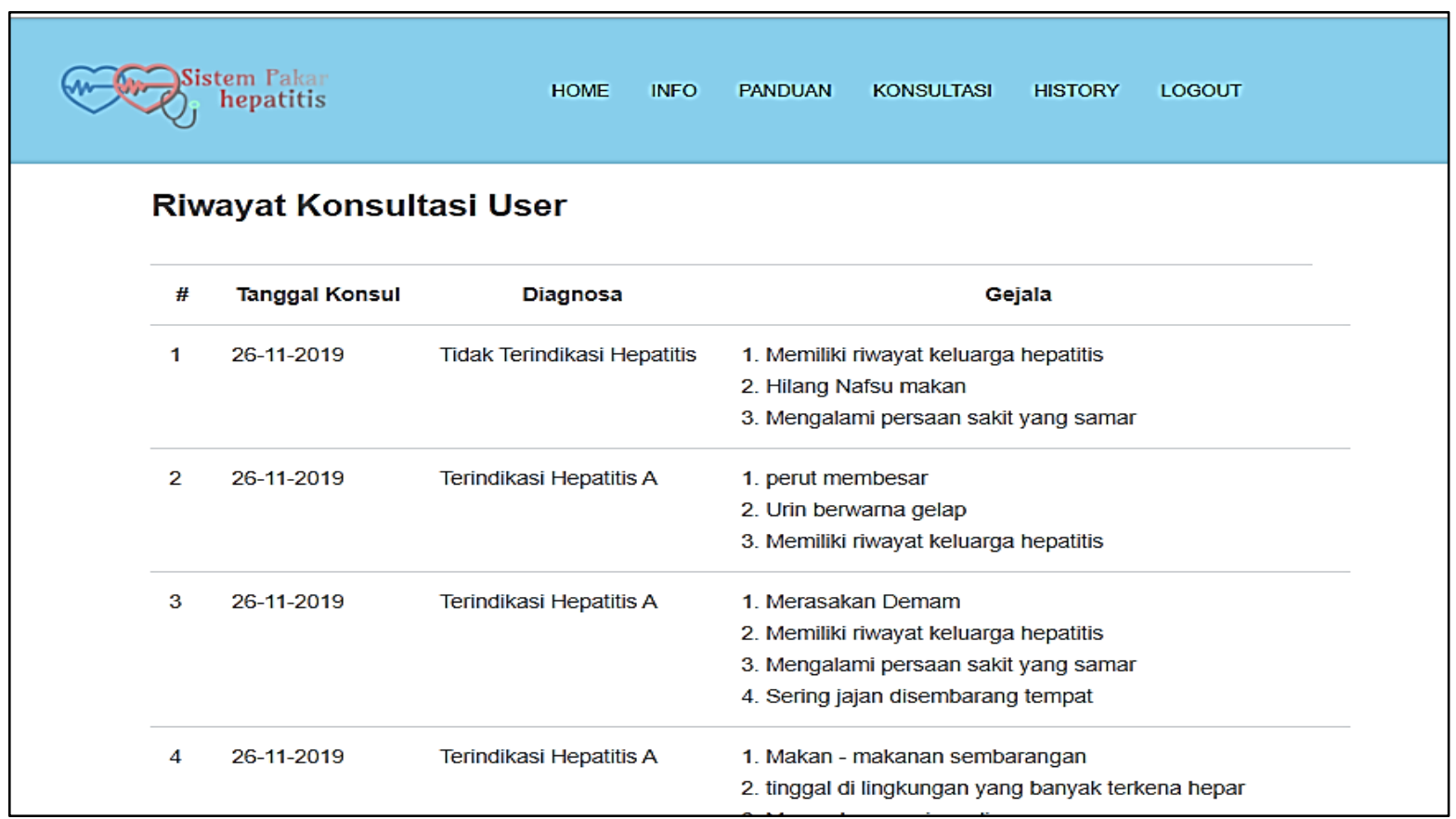

Gambar. 9. Tampilan halaman riwayat konsultasi.

Pada Gambar 9, merupakan tampilan riwayat konsultasi dari user yang telah menggunakan aplikasi ini, yang didalamnya berisi tanggal konsultasi, hasil diagnosa, serta gejala yang sebelumnya telah dipilih. 
III. HASIL DAN PEMBAHASAN

\section{A. Pengujian Sistem}

Pada tahap ini dilakukan pengujian untuk menghitung tingkat akurasi antara pakar dengan sistem. Pengujian ini dilakukan sebanyak 100 kali, dan dibawah ini terdapat sebagian sampel data, sebagaimana ditampilkan pada Tabel 6 .

TABEL 6

HASIL PENGUJIAN ANTARA PAKAR DENGAN SISTEM.

\begin{tabular}{clccc}
\hline \hline No & \multicolumn{1}{c}{ GEJALA } & DiAGNOSA SisteM & DIAGNOSA PAKAR & HASIL \\
\hline 1. & G12, G16, G18 & Tidak terindikasi & Tidak Terindikasi & Sesuai \\
2. & G6, G7, G12 & Terindikasi & Terindikasi & Sesuai \\
3. & G1, G12, G18, G30 & Terindikasi & Terindikasi & Sesuai \\
4. & G4, G5, G9, G11 & Terindikasi & Terindikasi & Sesuai \\
5. & G8, G13,G28 & Tidak Terindikasi & Tidak Terindikasi & Sesuai \\
6. & G6, G16, G22, G23 & Tidak Terindikasi & Tidak Terindikasi & Sesuai \\
7. & G19,G20,G26 & Tidak Terindikasi & Tidak Terindikasi & Sesuai \\
8. & G3, G22, G25 & Terindikasi & Terindikasi & Sesuai \\
9. & G9, G15, G17, G27 & Terindikasi & Tidak Terindikasi & Tidak Sesuai \\
10. & G13, G21, G25, G29 & Tidak Terindikasi & Tidak Terindikasi & Sesuai \\
11. & G4,G5,G9 & Terindikasi & Terindikasi & Sesuai \\
12. & G9,G13,G19,G22 & Tidak Terindikasi & Tidak Terindikasi & Sesuai \\
13. & G2,G3,G16 & Terindikasi & Terindikasi & Sesuai \\
14. & G4,G10,G16 & Terindikasi & Terindikasi & Sesuai \\
15. & G15,G24,G25,G28 & Tidak Terindikasi & Terindikasi & Tidak Sesuai \\
\hline \hline
\end{tabular}

Berdasarkan dari hasil pengujian sistem sebanyak 100 kali percobaan, dengan didampingi oleh pakar serta buku panduan yang telah diberikan, didapatkan hasil akurasi sebesar $92 \%$ untuk data yang sesuai dan $8 \%$ untuk data yang tidak sesuai. Untuk data yang sesuai antara pakar dengan sistem didapatkan hasil akurasi sebesar $92 \%$, dimana terdapat 92 data sesuai antara sistem dengan pakar, dan untuk akurasi yang tidak sesuai didapatkan hasil $8 \%$, dimana terdapat 8 data yang tidak sesuai, dikarenakan ada beberapa gejala yang ternyata terdapat pula di penyakit yang lain / termasuk kedalam gejala umum.

\section{B. Analisa hasil pengujian}

Pada pengujian sistem ini diperoleh hasil akurasi sebesar 92\% data sesuai dengan pakar, dan terdapat $8 \%$ data tidak sesuai dengan pakar, data uji sistem yang digunakan sebanyak 100 data uji yang diperoleh dengan mensimulasikan sistem tersebut, dengan melakukan 100 kali penginputan, dari gejala yang tersedia secara acak, yang selanjutnya hasil diagnosa tersebut dibandingkan dengan hasil diagnosa dari pakar, untuk mengetahui seberapa banyak data yang sesuai dan data yang tidak sesuai, agar selanjutnya dilakukan perhitungan untuk menentukan seberapa besar tingkat akurasi sistem ini.

\section{KESIMPULAN}

Dari hasil penelitian yang telah dilakukan oleh penulis, dapat ditarik kesimpulan bahwa, Metode Dempster - Shafer dapat diaplikasikan dengan baik pada pembuatan aplikasi sistem pakar hepatitis A dengan mendapatkan hasil akurasi sebesar 92\%, yang diperoleh dari 100 kali pengujian sistem yang sudah dilakukan dengan pakar, dan berdasarkan hasil akurasi yang diperoleh, sistem ini telah dapat digunakan untuk membantu pengguna, dalam melakukan diagnosa dini terkait penyakit hepatitis A, agar penyakit tersebut tidak bertambah luas.

Beberapa hal yang disarankan untuk pengembangan selanjutnya terkait penelitian ini agar lebih baik kedepannya seperti, menggunakan metode lain untuk sistem pakar penyakit hepatitis A, supaya nantinya dapat dilakukan perbandingan terkait hasil akurasi yang diperoleh, dan sistem yang dikembangkan selanjutnya disarankan dapat menggunakan platform lain seperti mobile agar lebih banyak pengguna yang dapat mengakses aplikasi ini. 
DAFTAR PUSTAKA

[1] S. P. Dr. J.B. Suharjo B. Cahyono, Hepatitis A Cegah Penularannya. Yogyakarta: Kanisius, 2009.

[2] A. Wahyudi, R. Efendi, and Y. Setiawan, "Perancangan Sistem Pakar Untuk Diagnosa Penyakit Pada Balita Menggunakan Metode Dempster-Shafer," J. Rekursif, vol. 6, no. 1, pp. 80-87, 2018.

[3] Srikandi Waluyo, 100 Question \& Answer Hepatitis. Jakarta: PT. Elex Media Komputindo, 2011.

[4] A. T. Novarina, E. Santoso, and Indriati, "Sistem Pakar Diagnosis Penyakit Hepatitis Menggunakan Metode Dempster Shafer," J. Pengemb. Teknol. Inf. dan Ilmu Komput., vol. 2, no. 6, pp. 2252-2258, 2018.

[5] A. T. Hidayat and K. I. Ibraheem, "Human Facial Disease Diagnosis System Using" Ahmad Tri Hidayat , Suhirman , Kais Ismail Ibraheem Ahmad Tri Hidayat, Suhirman, Kais Ismail Ibraheem,” vol. 1, no. 1, pp. 6-12, 2019.

[6] D. Leman, "Expert System Diagnose Tuberculosis Using Bayes Theorem Method and Shafer Dempster Method," 2018 6th Int. Conf. Cyber IT Serv. Manag. CITSM 2018, no. Citsm, pp. 1-4, 2019.

[7] R. Setiawan, C. Suhery, and S. Bahri, "Implementasi Metode Dempster Shafer Pada Sistem Pakar Diagnosa Infeksi Penyakit Tropis Berbasis Web," J. Coding, vol. 06, no. 03, pp. 97-106, 2018

[8] D. W. Utomo, Suprapto, and N. Hidayat, "Pemodelan Sistem Pakar Diagnosis Penyakit pada Sistem Endokrin Manusia dengan Metode Dempster Shafer," J. Pengemb. Teknol. Inf. dan Ilmu Komput., vol. 1, no. 9, pp. 893-903, 2017.

[9] S. Abriani, K. Mukhoyyaroh, and M. U. Siregar, "Recommendation System of Self-Medication for Mild Digestive Diseases with Dempster Shafer Method," Ijid, vol. 3, no. 1, pp. 1-7, 2014.

[10] Rika Rosnelly, Sistem Pakar : Konsep dan Teori. Yogyakarta: CV Andi Offset, 2012.

[11] A. M. Alfatah, R. Arifudin, and M. A. Muslim, "Implementation of Decision Tree and Dempster Shafer on Expert System for Lung Disease Diagnosis," Sci. J. Informatics, vol. 5, no. 1, p. 57, 2018.

[12] D. I. G. Hutasuhut, D. Adhar, Nurhayati, E. Ginting, and A. Syahputra, "Expert System Detect Stroke with Dempster Shafer Method," 2018 6th Int. Conf. Cyber IT Serv. Manag. CITSM 2018, no. Citsm, pp. 1-4, 2019.

[13] K. Kirman, A. Saputra, and J. Sukmana, "Sistem Pakar Untuk Mendiagnosis Penyakit Lambung Dan Penanganannya Menggunakan Metode Dempster Shafer," Pseudocode, vol. 6, no. 1, pp. 58-66, 2019.

[14] W. Fahrozi, A. Syahputra, C. B. Harahap, and F. Harahap, "Expert System of Diagnosis Impairment Nutrition the Thin Body by Dempster Shafer Method,” 2018 6th Int. Conf. Cyber IT Serv. Manag. CITSM 2018, 2019.

[15] D. M. Khairina, H. R. Hatta, R. Rustam, and S. Maharani, "Automation Diagnosis of Skin Disease in Humans using Dempster-Shafer Method," E3S Web Conf., vol. 31, pp. 1-7, 2018. 